\title{
Bukaresti magyarokról, otthonról és hazáról
}

Hogy? Bukarestben élnek magyarok? Hogy kerültek ők oda? Tették fel a kérdést 100 éve és most is sokan. A madéfalvi veszedelem után, majd 1848/49-es forradalom és szabadságharc leverését követően a Habsburgok önkénye elöl menekülve Erdély területéről sok magyar gondolta úgy, hogy Bukarestben keres új hazát magának. A 19. század végén románosan magyar és magyarosan román nyelvezetük miatt a „bangyen” csúfnevet akasztották rájuk. A két világháború között - miután az erdélyi magyar és a bukaresti magyar egy ország fedele alá került - már kitüntetés volt „,bangyennek” lenni, hisz keresett és megbecsült volt a magyar munkaerő Bukarestben. Ezzel együtt hatalmas szakadék tátongott a „régi” - háború elött is ott élő - és az „új” - a háború után a román fơvárosban egzisztenciát kereső - magyarok között. A „ki a bukaresti magyar?” égető kérdése minden addiginál metszőbben merült fel a „régiek” és az „újak” között. Bár a közvélekedéssel ellentétben Bukarest nem lett a második legnagyobb magyar város Budapest után, de jelentős számú magyar dolgozott a háború utáni román fővárosban. A második világégést követően már erősen megkopott a bukaresti egzisztenciaépítés lehetőségének fényessége, az odavándorlás kisebb mértékben, de továbbra is folytatódott, mígnem a rendszerváltozást követően a kinyíló nyugati világ csábítása magával ragadta az erdélyi magyarokat is, és azóta már csak leginkább a kalandvággyal felvértezett honfiak keresik ott jobb megélhetésüket. De a régiek vannak, és bár csökkenő számmal, de maradnak, és világító mécsesként viszik tovább a bukaresti magyar közösséget.

Első találkozásom egy „hús-vér” bukaresti székely emberrel a 90-es évek végén az ELTE Idegen Nyelvi Lektorátusa előtti folyosón volt egy vizsgára várakozva. Emlékeimbe a találkozásból egy mondat vésődött: „Budapesten a magyarok kutyát tartanak, ahelyett, hogy szülnének. Mi még inkább gyereket szülünk.” - mondta a Bukarestből jövő nemzettársunk.

Ezt követően 2014-ben, az első bukaresti kutatómunkám alkalmával, miután a fóvárosban a totális idegenség érzetét éltem meg, mivel senkihez nem tudtam magyarul szólani, gondoltam, vallási identitásomban keresem meg az otthonosságot, hogy oldjam egy kicsit az idegenségérzetemet. Az ortodox Bukarestben bementem

\footnotetext{
* A szerző történész, a Társadalomtudományi Kutatóközpont Kisebbségkutató Intézet munkatársa. E-mail: Marchut.Reka@tk.hu
} 
az Olasz Római Katolikus Templomba egy misére. Nagy csodálkozásomra a mise kezdetét jelző csöngetés után egy fekete bőrü pap jelent meg az oltárnál. Éreztem, hogy megtört bennem az egyedüllét érzése, tekintetemet az égre emeltem, és mosolyogva mondtam a Fennvalónak: „Istenem, van Neked humorod!” Ott abban a pillanatban, hogy rajtam kívül van még legalább egy idegen, felszabadítóan jóleső érzéssel töltött el, mert az idegenség is jobb, ha legalább ketten vagyunk.

Még ugyanabban az évben tett második bukaresti utam során világosítottak fel, hogy akár magyar misére is elmehetek a Barátok templomába. „Bár a pap nem is tud magyarul, szóval elmenni sem érdemes oda." - mondta egy magát igaz bukaresti magyarnak tartó hölgy. Ezzel annyira felcsigázta az érdeklődésemet, hogy csak-azért-is elmentem vasárnap 9 órára a Barátok templomába. És belecsöppentem a bukaresti magyar világba, ahol a miséző atya olyan gyönyörü csángós magyarsággal tartotta a prédikációt, amely nem csak nyelvezetében, hanem tartalmában is felemelö volt. Annyian voltak a magyar misén, hogy állóhely is alig volt, és a Miatyánk utáni kézfogás (jó, hogy akkor nem volt járvány) a bukaresti tartózkodásom egyedüli emberi testi érintkezése volt.

Ezek után már nem volt kérdés, hogy mindent, ami tőlem telhető, szeretnék megtenni ezért a közösségért. Így volt már részünk két közös zarándoklatban és több közös bukaresti élményben, és persze mivel történész vagyok, természetszerüen kezdtem el érdeklődni a múltjuk iránt.

A Kutatók Éjszakája apropóján azonban a jelenükre kérdeztem rá. Arra, hogy mit tartanak ők hazának és otthonnak? 27 válaszadó alapján: a haza az, ahol a gyökereim vannak, ahol a családom él, ahol nevelkedtem, ahol iskolába jártam, ahová a szívem húz; ahol tudom, hogy szeretettel várnak és megbízhatok az emberekben; amikor a szülöfalumba érek; ahol mindig várnak rám, miután bebarangoltam az egész világot, ahol a rokonaim a temetőben nyugszanak, ahol a kislányaim az ajtóban fogadnak, hogy segítségre van szükségük, a férjem éhes, a kiskutyát pedig sétálni kell vinni. Ezek mind olyan válaszok, melyeket a világ bármely pontján élő más emberektöl is hallanánk. Mondhatjuk azt is, hogy nem ez a bukaresti magyarok differentia specifikája.

Akkor mégis mi? A válaszoknak ez a része: haza megyek, amikor Erdélybe megyek, amikor magyar közösségbe megyek, amikor Bukarestbe visszatérek, amikor a Barátok templomába misére megyek, amikor belépek a csíksomlyói kegytemplomba. Egyetlen olyan válasz sem volt, hogy haza megyek, amikor átlépem az országhatárt.

Ezt a képet némileg árnyalja, amikor arra kértem a válaszadókat, hogy konkrétan jelöljék meg, hogy mit tekintenek hazájuknak és otthonuknak. A válaszadók csaknem fele csupán Erdélyt jelölte meg hazájának, és ha hozzávesszük azokat a személyeket is, akik Romániát vagy Bukarestet is megjelölték, akkor azt mondhatjuk, hogy a válaszadók több mint fele Erdélyt hazájának tekinti. Ezzel szemben Románia mint kizárólagos haza csak a válaszok harmadában szerepelt, Románia 
mellett Erdélyt további két fö, Bukarestet pedig további egy fő választotta. Magyarországot két fö kivételével, akiknek Magyarországon is van lakhelyük, senki nem tekintette hazájának. A válaszadók többsége számára tehát elsősorban nem az országhatár által körbezárt földrajzi terület jelenti a hazát, hanem a haza egy kulturális szellemi közösséghez, történeti örökséghez való tartozás kifejeződése, ami a bukaresti magyarok többségénél Erdélyt jelenti.

Mondhatjuk-e ezután azt, hogy a Kós Károly által Trianon után elképzelt transzilvanizmus csupán naiv vágyálom volt, ami soha meg nem valósult? Vagy inkább mondjuk azt, hogy a transzilvanizmus a maga teljességében ugyan nem valósult meg, de a transzilván gondolat mind a mai napig a terület szülötteinek identitásmeghatározó eleme. Vélelmem szerint mondjuk inkább ez utóbbit. Mondom ezt nem csupán kutatóként, hanem nagykárolyi születésü, Magyarországon élö, erdélyi magyarként is.

Végül köszönöm ezúton is mindenkinek, aki válaszolt a kérdéseimre. És külön köszönöm azt, hogy amikor a Barátok templomába megyek, bár nem vagyok bukaresti magyar, mégis egy kicsit otthon érezhetem magam. 